\title{
Cheyenne Odyssey: Representing Removal in an Educational Video Game*
}

\section{Christina Gish Hill}

\begin{abstract}
This articles reflects on the process of creating digital media in collaboration with Native communities, using the example of Cheyenne Odyssey, a game from Mission US, to argue that such media can illuminate the perspectives of Indigenous peoples for a wide audience while also creating digital repositories for both visual and narrative forms of knowledge. This game takes on the difficult challenge of portraying very sensitive moments of US history to middle school-age children. The game walks the player through the Battle of Little Big Horn, the forced removal of the Northern Cheyenne people, their harrowing journey home again, and even the massacre of Dull Knife's band at Fort Robinson. The creators of the game brought Cheyenne perspectives to the process by consulting Northern Cheyenne elders, historians, and even school children, as well as archival materials, and scholars of Cheyenne history, including the author. This multifaceted collaboration resulted in a game that presented Cheyenne history in a way that reflected Cheyenne values while providing non-Cheyenne people with an accessible narrative that, nevertheless, disrupts the familiar history of westward expansion in the United States. At the same time, the game makes new a history familiar to every Cheyenne by presenting it in a fresh medium that captivates young people. The public nature of this online game empowers Cheyenne people to take pride in their own historical narratives.
\end{abstract}

[Keywords: Cheyenne; digital media; Indigenous peoples; video games; regional histories; cultural heritage; educational materials. Keywords in italics are derived from the American Folklore Society Ethnographic Thesaurus, a standard nomenclature for the ethnographic disciplines.]

When the group Mission US (an educational materials development company associated with Public Broadcasting Service affiliate WNET), asked me to consult on their online game, Cheyenne Odyssey, my first thought was, "What can I offer a video game?" I have come to learn that anthropologists have a great deal to offer to digital media production projects. Mission US invited me to consult on the game because I had carefully researched the removal of Northern Cheyenne people from the Black Hills region, south to Indian Territory in modern Oklahoma. I had been to archives and sifted through countless materials on this removal. I had also been to the Northern Cheyenne reservation and talked with people about their ancestors' experience of

- This peer-reviewed contribution was accepted for publication in Museum Anthropology Review on May 9, 2017. The work is licensed under the Creative Commons Attribution 4.0 International License. To view a copy of this license, visit http://creativecommons.org/licenses/by/4.0/ 
this journey. I wrote my dissertation about the circumstances leading to the removal and the long, difficult journey north of a small band of Cheyenne led by Dull Knife and Little Wolf, who had essentially broken away from the Southern Cheyenne and Arapaho reservation. My research experience meshed with the needs of Mission US because the video game would allow players to follow a Cheyenne youth as he personally experienced these tumultuous changes for his community. Through my participation in this project, I realized creating digital media in collaboration with communities is a dynamic tool that can illuminate the perspectives of Indigenous peoples for a wide audience while also creating digital repositories for both visual and narrative forms knowledge.

From its inception, anthropology has attempted to immerse Western peoples in Indigenous worlds, by familiarizing readers with cultures that seemed strange to them. It has also had a long history using visual media to communicate across cultures (Cohen and Salazar 2005). Likewise, the digital media produced today has a profound ability to empower communication both within and among cultures. Unlike the journal articles and ethnographies that anthropologists commonly publish, digital representations of Indigenous worlds are easily accessible to essentially everyone, including those being represented. While the representation of any group in either scholarship or media demands a responsibility towards those presented, the easy and wide ranging representation that digital media provides raises specific concerns over production and dissemination for many Indigenous people. At the same time, when created with careful attention to Indigenous protocols, digital materials can be quite useful to Native communities. This media has the power to make familiar narratives or cultural objects new and exciting for communities, particularly their younger members. It also can create digital cultural objects that preserve a vast array of cultural knowledge, from artwork and material culture to language and narrative. Digital media also allows for wide distribution that can be hard to contain. This creates another set of ethical concerns, but it also contains transformative power. As Gwyneira Isaac has noted, digital media has "the potential to construct relationships and, therefore, to transform the current social order" (Isaac 2015, S286). While it is important to note that Native communities choose to create digital media without collaborations with external scholars, this paper addresses the experience of collaboration between anthropologists, linguists, curators, and Indigenous communities, arguing that the process can produce digital media that builds bridges between Indigenous peoples and the wider society, leading to a critical but accessible encounter with Indigenous cultural perspectives for non-Native peoples as well a powerful way for Native peoples to disseminate traditional knowledge within their own community. To illustrate the potential of collaboration, I propose that the game Cheyenne Odyssey contains transformative power through its validation of Cheyenne historical perspectives in mainstream educational materials that work to both empower Native peoples and, at the same time, disrupt hegemonic ideologies held by many non-Native people.

Because they present a more personal experience, first-person games like Cheyenne Odyssey (http://www.mission-us.org/pages/landing-mission-3), which allow a player to embody a specific character, can be particularly powerful vehicles for presenting cultural and historical information (Mission US n.d. a). Cheyenne Odyssey takes on the difficult challenge of portraying very sensitive moments of US history to middle school age children. The game walks the player through the Battle of Little Big Horn, the forced removal of the Northern Cheyenne people, their harrowing journey home again, and even the massacre of Dull Knife's band at Fort Robinson. 
Both Cheyenne and Euro-American people feel very sensitive about these topics. The Battle of Little Big Horn, during which Cheyenne and Lakota warriors killed General George A. Custer and all of his men, remains an embarrassment to Euro-Americans. The federal Indian removal policy leaves a black mark on the nation, as does the massacre of innocent elders, women, and children at Fort Robinson. Mission US took on the formidable task of presenting policy mistakes and even genocidal moments in US history to middle school children. For the Cheyenne, these experiences have become a treasured part of their national history. The victory at Little Big Horn is a proud historical moment that until recently went unrecognized at the battlefield monument. Removal and the Fort Robinson massacre are some of the darkest days in Cheyenne history and families still recount the personal histories of members who survived these brutalities. They detail the profound suffering people endured in their fight to retain their community and culture. These histories are foundational to the current Northern Cheyenne understandings of cultural and national identity (Hill 2017). It is important to note that while the Southern Cheyenne of Oklahoma and the Northern Cheyenne of Montana see themselves as one nation, these two groups experienced different histories. Cheyenne Odyssey does incorporate Southern Cheyenne experiences, but mainly focuses on a historical moment that disproportionately impacted northern bands. The game attempts to portray both the history and the culture of Cheyenne people as accurately as possible, privileging a Northern Cheyenne voice while presenting a challenging historical narrative in a way that engages a wide audience.

In the strict sense of the term, Cheyenne Odyssey is not Indigenous media, which refers to Indigenous control of the images and narratives placed in the public sphere, creating opportunities to both promote Indigenous interpretations and challenge stereotyped and inaccurate representations of Indigenous people in dominant society (Duarte and Belarde-Lewis 2015; Ginsburg 1991; Isaac 2015; Iseke and Moore 2011:21; Turner 1992; Worth and Adair 1997). Indigenous media emerges from initiatives within Native communities. Instead, Cheyenne Odyssey was originally conceived by Mission US The game developers then sought scholars and Cheyenne elders to consult on the production of the game. While one of the goals of the game is to validate Cheyenne perspectives while dispelling one dimensional views of US westward expansion, the game did not develop as Indigenous media. The project did not emerge from initiatives in the community, nor was it predominantly controlled by Cheyenne. Nevertheless, it did solicit substantial input from the people. The creators of the game brought Cheyenne perspectives to the process by consulting Northern Cheyenne elders, historians, and even school children, as well as historic interviews conducted with people who experienced these events, a historian, Jeffery Ostler who is familiar with the archival materials, and myself, an anthropologists who had worked in the community researching this specific history. Ostler and I read scripts and played early versions of the game looking for inaccuracies, while community members also provided similar feedback, as well as providing actors and music to bring the game to life. This multifaceted collaboration resulted in a video game that presented Cheyenne history in a way that reflected Cheyenne values while providing non-Cheyenne people with an accessible and intimate understanding of a very painful moment in both Cheyenne and US history. Cheyenne Odyssey disrupts the familiar history of westward expansion in the United States for non-Native players by using a Cheyenne context to counter these dominant narratives. It rebukes the stereotyped presentations of Plains people in US history, providing non-Native players with alternative perspectives. At the same time, the game makes new a history familiar to every Cheyenne by presenting it in a fresh medium that captivates young people. The public 
nature of this online game empowers Cheyenne people to take pride in their own historical narratives.

\section{The Game}

Mission US works to create educational video games designed to be used in middle school classrooms to help teach US history requirements (Mission US n.d. b). Cheyenne Odyssey, the third game that the group created, was developed to address the information students were required to learn about westward expansion across the Plains, while telling a compelling story that captivated middle school students. Mission US now has five video games set in different moments of US history. The funding for these games comes from the Public Broadcasting Service (PBS), the National Endowment for the Humanities (NEH), and the US Department of Education. They are available free to the public and include curricular materials for use by teachers. Mission US seems committed to maintaining these games for the public because not only have they kept the site going for five years, they are have created versions of the games that are compatible with Apple iPad and with Google's Android tablet operating system. These games are all first-person games, where the player takes on the persona of the main character in the game, making choices for this character as he or she navigates through the momentous historical changes occurring in the character's world. This premise allows the players to imagine important historical moments from the perspective of a young person experiencing them. The main characters begin their adventures at the age of the target audience, thirteen or fourteen years old, making them easy for the player to identify with. Three of the five video games employ a young person from an ethnic minority as the main character-an African American slave girl during the Civil War, a Cheyenne boy during US westward expansion, and a Jewish Russian immigrant girl during the labor movement. The fourth game tells the story of an American born youth of British decent during the Revolutionary War period and the fifth portrays a family trying to save their farm during the Great Depression. Students not only experience US history from the perspective of a person around their age, three of the games also allow them to experience it from a non-dominant perspective. For such games to be successful, however, the creators must be sensitive to producing both an accurate historical and cultural portrayal.

Cheyenne Odyssey is about Little Fox, a Cheyenne youth coming of age as the westward expansion of the 1860s puts more pressure on the Native peoples of the northern Great Plains. As he grows older and begins to travel with war parties, Little Fox participates in an attack on a train, in the Battle of Little Big Horn, and ultimately experiences first hand the brutality of the federal removal policy, walking with his family to Indian Territory (present-day Oklahoma). He escapes with Dull Knife and Little Wolf to return to his homeland in the Powder River Region of what is now Montana. The video allows the player to follow a Cheyenne youth as he experiences these famous moments in US history, getting a first-hand perspective of what it might have been like to have lived through such tumultuous events. The player makes choices that teach him or her about these historical moments, as well as Cheyenne culture. The people the player encounters in the game teach about the specifics of Cheyenne culture through interpersonal interactions. For example, if Little Fox tries to have a conversation with his sister, the player learns that Cheyenne brothers and sisters maintain respect relationships. Depending on his or her choices in the game, the player can collect badges reflecting Cheyenne skills and values. The Value Badges represent 
four characteristics that are recognized as important in Cheyenne culture: Bravery, Craziness, Generosity, and Wisdom. The Skill Badges reflect specific skills that the Cheyenne expected men to develop proficiency in during the nineteenth century: Archery, Riflery, and Horse Sense (Hill 2016a). By making thoughtful choices, each player can demonstrate their character's mastery of such abilities while learning about Cheyenne culture. For example, towards the beginning of the game Little Fox realizes the horses he is supposed to guard have gone missing. He must decide if he should search for the lost horses on his own or tell an older relative that they are missing (Hill 2016c). An independent search might result in points for bravery, while seeking help from a relative might result in points for wisdom, depending on how each activity is pursued. By attaining rewards for accomplishing culturally relevant tasks, students learn about Cheyenne perspectives in a more relatable manner than a textbook can present.

Players can also earn an English badge for language learning during the game. I had several conversations with the creators of the game addressing the use of language. A historically accurate depiction of Cheyenne history would use Cheyenne language, but everyone involved acknowledged that the majority of the game must occur in English because most of its audience - both Cheyenne and non-Native - does not speak Cheyenne fluently. At the same time, Cheyenne collaborators wanted to make the language a part of the game, so the beginning of the game is entirely in Cheyenne with English subtitles. Finding a balance between creating an accessible game while privileging Cheyenne perspectives encouraged us to brainstorm a way to privilege the Cheyenne language while retaining game play in English. We decided that while having a Cheyenne language badge might encourage language revitalization, this game would not be able to adequately meet such a goal while reaching a wide audience. Furthermore, creating a Cheyenne language badge for a Cheyenne character might devalue the language, implying that it was not natural to speak Cheyenne. We felt that we needed to somehow point to the language difference, though, or this would be an issue that players would simply gloss over and fail to consider. They might even assume English speaking Cheyenne people as the baseline. In order to avoid this, we decided to emphasize the language difference through an English language badge. I argue that this badge actually reverses the dominant narrative that English is the language of American history. Here English is the foreign and othered language-the language of newcomers, learned to gain power in new relationships, not as a concession to EuroAmericans. In the game, to learn English is a choice and not a necessity. For the player to learn Cheyenne, this would require breaking the first person player positionality. Cheyenne becomes the foreign language as opposed to the Indigenous language. While players will not acquire any Cheyenne, this is not the purpose of the game. It is not meant as a language learning tool. It is meant to privilege a Cheyenne perspective on history. Othering English is a powerful tool to destabilize a non-Native student's sense of the "naturalness" of American history. Perhaps it might also give Cheyenne students pause as they reflect on a time when their ancestors would have heard very little English.

The player is faced with many decisions through out the game. Ultimately, the choices that each player makes will affect Little Fox's fate, sometimes in profound ways. There are minor ones, like what to do about the missing horses, and there are major ones, like whether to join the warriors during the Battle of Little Big Horn or help Little Fox's sister search for her missing child. Many of the decisions that Little Fox faces revolve around the difficult choice of whether to adapt to the changes brought by Euro-American encroachment or to fight for the Cheyenne 
way of life. By traveling to an American fort to trade hides and participating in a raid on a train, the player learns about the implications of these two different choices. He or she discovers that some Cheyenne people embraced these changes while others fought them, and that most Cheyenne people embraced some changes and fought others. The player learns of the benefits and struggles that come from interacting with Euro-Americans through Little Fox's experiences at the trading post and at the agency (Hill 2016h). He or she also learns that some Cheyenne people had good reasons for fighting Euro-Americans. For example, the character, Porcupine, plans attacks on Euro-Americans with little remorse, but if the player asks why, he or she is told that his family was murdered by the newcomers.

The player must also make momentous decisions like whether to join Little Wolf or Dull Knife when they split into two groups on the journey home. Depending on the choice, the player will either end up passing the winter in peace or experiencing a massacre. The power of these choices is impressed on the player because the outcome of a decision might mean suffering or even death. Little Fox witnesses starvation, sickness, and violent death, yet the player can take comfort in the fact that the protagonist survives. Every narrative path ends with Little Fox living with his wife and children on the Northern Cheyenne reservation, but the possibilities open to players give a sense of the gravity of the choices Cheyenne people were faced with as a result of the encroachment of Euro-Americans onto the plains.

Cheyenne Odyssey presents the player with depictions of some very violent moments in American history, including the Battle of Little Big Horn and the Fort Robinson Breakout. Little Fox is coming of age during a tumultuous era for Plains peoples. When General George Armstrong Custer and his men enter the Big Horn River Valley in 1876, Little Fox is old enough to join the fighting men and the player can follow him into battle. S/he witnesses, through Little Fox's eyes, the death of Custer and his men. After the battle, Little Fox experiences the brutality of removal and life in Indian Territory (Hill 2016d). He also must make choices about his family, understanding that they might need to separate to survive. He struggles north with Dull Knife and Little Wolf, experiencing violence and depravation along the way. If the player chooses to travel with Dull Knife when his group separates from those with Little Wolf, s/he experiences Little Fox's journey to Fort Robinson. S/he learns that Dull Knife's people are cared for by military men at the fort until they receive orders from the federal government to return these Cheyennes to Indian Territory. The people refuse to leave and are locked in army barracks with no food or water. Little Fox participates in the Breakout, where young men fight off soldiers while the rest of Dull Knife's people attempt to escape from the barracks and flee the fort (Hill 2016i).

While Little Fox survives the journey north from Indian Territory and the Fort Robinson Breakout regardless of the choices the player makes, the game does not sugar coat this history. During the Breakout in 1879, over a third of the people held at Fort Robinson were killed. Such events may seem extreme for children's educational materials, yet the game's creators have worked hard to portray these violent moments honestly and tastefully. In doing so, the game creates a powerful learning experience for players. Neal Shapiro, president and CEO of WNET, the PBS affiliate that produced the game, has stated in a WNET Press Release that, "Mission US taps into the ways 21 st century students learn and explore content. Through immersive digital media and the engagement of gaming, students 'live' history and learn through experiences only 
this multimedia approach can deliver" (Thirteen/WNET 2013). By learning through experiencing historical events through the eyes of a Cheyenne youth, students gain a more personal perspective on some challenging moments in US history. For this reason, students more easily retain the content, but they also learn to listen to multiple perspectives, complicating the hegemonic national narrative they most often encounter. One review of the game touted that, "It's a great starting point for dialogue and a chance for kids to do a lot of critical thinking" (Matte 2013).

Richard Littlebear, the President of Dull Knife College in the Lame Deer District on the Northern Cheyenne Reservation and advisor to the project, recognized that confronting the difficult moments in Cheyenne history engages Native students as well. He pointed out that, "this is much more than a game about the high and low points of our history. It teaches students how to make decisions and how to live with the consequences of those decisions, just as one has to do in real life" (Thirteen/WNET 2013). By providing students with a specific perspective and engaging them with storytelling using a medium they find compelling, Cheyenne Odyssey provides a potent vehicle for teaching the history of western expansion in the United States.

\section{Countering Dominant Narratives}

Cheyenne narratives of US western expansion contradict hegemonic nationalist narratives of the triumphal progression of civilization in many ways. While Euro-Americans often imagine westward settlement as "taming the wilderness" and "advancing civilization," Indigenous peoples recount land theft, resource destruction, and violence (Brayboy 2005; Duarte and Belarde-Lewis 2015). For the Northern Cheyenne, their specific history of removal and the struggle to return to their homeland in Montana is both painful and proud. Over time it has become a national narrative that explains the political origins of the current reservation from a Cheyenne perspective. The events, and some of the people, portrayed in this video game are commemorated as part of this history. The tribal college is named after Dull Knife. The government building is named after Little Wolf. Children are taught this history in their schools and the Breakout is commemorated by the community at Fort Robinson every year. The tribe has even purchased land near the site of the massacre and erected a monument so that the general public can learn about the event from a Cheyenne perspective. This history is very powerful for Northern Cheyenne people and, therefore, they rightfully are concerned with its representation.

At the same time, the history of Cheyenne removal and of Dull Knife's struggle to return home has been represented over and over in wider US narratives of western expansion. Because it was a highly publicized massacre, narratives surrounding the Fort Robinson Breakout have been popular among Euro-Americans since the time it happened. Marisa E. Duarte and Miranda Belarde-Lewis note that one "marker of an expansionist ideology is the suppression of Indigenous histories" (Duarte and Belarde-Lewis 2015). Although many non-Natives decried the massacre as atrocious immediately after the event, the narratives that emerged still worked to erase Cheyenne perspectives of the event. While this massacre and other events in the late 1870s and 1880s forced Euro-Americans at the time to rethink their Indian policies, the discourse surrounding the Breakout devolved into simplistic representations of Cheyenne people as either blood-thirsty savages or as noble victims doomed to extinction when faced with western 
civilization. When represented as bloodthirsty savages, the Fort Robinson killing is described as a necessary control of wild people who would not settle in their proper place, and therefore threatened Euro-American settlement in the west. When represented as noble victims, the Breakout is understood as the inevitable outcome of the clash between Indigenous people who refused assimilation and more advanced cultures that overtook them as the result of a natural progressive development. As a result, both narratives have often been used to reinforce the supposed inevitability of Euro-American settlement as hegemonic US history.

Ethnographers and Indigenous peoples have recognized that the creation of digital media can produce materials that reinforce these stereotyped narratives and misrepresent Indigenous communities (Iseke and Moore 2011, 31). Default virtual representations are white and masculine (Coleman 2010, 492; Eglash and Bennett 2009). In most digital media, especially video games, Native people are either left out of the story completely or stereotyped as savage warriors or mystical medicine men. Most media validates hegemonic narratives focused on EuroAmerican movement west and the struggles of these families to settle in a new landscape. It usually emphasizes technology, assuming that the development of new technologies like the plow, the telegraph, and the railroad equate to progress. In this narrative, American Indian people either represent a barrier to progress as the bloodthirsty savage or a victim of progress as the noble savage. The rich diversity of Native peoples, histories, and cultures has rarely been represented. Even media that utilizes narratives inspired by US history most commonly fails to create nuanced representations of American Indian people, if they include Native characters at all. Because the default representations are white and masculine, this media never challenges the assumption that white men propel US history. By portraying the standard representations of Native peoples as either bloodthirsty savages or noble victims, often even the newest video games work to underscore the hegemonic nationalist narrative of western expansion in the United States.'

Cheyenne Odyssey departs from this narrative because it privileges a Cheyenne perspective on US history. The Northern Cheyenne do not perceive their own historical experience of the Breakout as either the result of wild and bloodthirsty factions among their own people or the result of an inevitable triumph of Euro-American civilization over Indigenous peoples. Northern Cheyenne tellings reinforce cultural worldviews at both the familial and the national level. Cheyenne families recall the struggles and bravery of their ancestors who took part in these historical events, passing narratives down to their children so that these struggles will continue to inform and shape future generations. The Northern Cheyenne nation recounts the history of the journey and the massacre at Fort Robinson to promote collective pride and to bolster a national identity, including claims to the landscape of the Northern Cheyenne reservation. By incorporating Cheyenne perspectives that emphasize survival over victimhood, the game has created a digital narrative that disrupts the dominant valorous narrative of westward expansion in the United States. By reflecting the Cheyenne focus on returning home to a beloved landscape instead of the hegemonic focus on military might, it undermines the stereotype of the bloodthirsty savage.

The narrative does not focus on the struggles of Euro-Americans to settle the frontier; instead it focuses on Cheyenne struggles that resulted from the new pressures created by this encroachment. It has very few non-Native characters and they are all peripheral to the narrative. 
It allows players to gain insight into why Cheyenne people would attempt to rob a train or participate in famous battles, like the Battle of Little Big Horn. The reasons emphasize Cheyenne humanity and necessity while illuminating the challenge of adapting to the swift changes created by Euro-American encroachment. The depiction of the railroad in the game serves to illustrate this point. While the railroad has represented progress for generations of Euro-Americans narrating westward expansion, it meant something completely different for Plains peoples like the Cheyenne. The railroad was a powerful representative of Euro-American intrusion into Plains Indian territory, and represented not only broken treaties but also the slow erosion of Plains Indian control over their traditional territories.

Part of undermining the hegemonic narrative of settling the North American West involves acknowledging that encroachment was not inevitable because it involved exploitative subjugation (Duarte and Belarde-Lewis 2015). Choosing to educate students about western expansion in the United States from a Cheyenne perspective necessitates addressing the coercive violence they experienced if the materials attempt to present the narrative accurately. This was a risky choice for Cheyenne Odyssey. One review describes the violence in the game in this way, "Kids can use guns and arrows against other people and destroy or steal others' property. There are discussion of acts such as burning down teepees and raiding. People die, but there's nothing graphic shown on-screen. Kids don't pull any triggers. They make choices about how a character will act. The website includes suggestions on discussing the game's violence with kids" (Matte 2013). While most reviews of the game are complimentary regardless, some suggest that the violence can be overwhelming for children (Matte 2013; Powers 2014).

One reviewer criticized the game, arguing that, "Kids will have to make decisions that would be morally questionable by today's standards, and some kids may find the content to be upsetting" (Matte 2013). Considering the level of violence most children are exposed to through media today, one has to wonder if the critique stems not from the amount of violence, which is quite mild considering the reality of this history, but instead from who is participating in the violence. The critiques are mainly concerned with the player's ability to choose a violent response for Little Fox in certain scenarios, for example shooting the train conductor during the raid on the train (Hill 2016i). Yet the game provides thoughtful reasons for every act of violence Little Fox might choose to enact, skillfully undermining the bloodthirsty savage of hegemonic US history. The game reminds players that while the violent response of Native peoples to Euro-American encroachment was often justified, it must have presented ordinary people like Little Fox with painful choices. Such a profound disruption to the valorous narrative of US western migration might certainly be upsetting to some. Reviewers have shown almost no concern with the depictions of violence perpetrated on the Cheyenne by Euro-Americans, perhaps because the hegemonic narrative portrays this violence as inevitable.

Cheyenne Odyssey carefully depicts Cheyenne engagement with Euro-American encroachment in a complex light, however, revealing to players that the people also embraced some of the advantages brought by closer ties with these newcomers, particularly through trade for horses, guns, and other useful objects like knives, cloth, and cooking pots. The characters are presented as multidimensional people making difficult decisions. Often Little Fox must consider his family when he is making decisions, reminding players that Euro-American settlement disrupted entire Plains communities. In this way, the game demonstrates that the Cheyenne were not simply 
warrior-like people reacting to settlement through violence. They had an entire communal history within a particular landscape. So when they acted, they made decisions that affected the trajectory of US history just like Euro-Americans did. As an educational component of US curriculums, Cheyenne Odyssey brings a different perspective to the dominant narrative, informing students that Native people were not simply swept up in someone else's history. They learn that American Indian history is also American history.

\section{Collaboration in Crafting Digital Technologies}

Most digital media currently perpetuates dominant Euro-American narratives, but creating media in collaboration with Native peoples has worked to complicate such simplistic representations. As Ramesh Srinivasan has argued, digital technologies have often been used to reinforce structures of power, and therefore have also worked to create hierarchical inequalities (Srinivasan 2006). By reinforcing common stereotypes associated with American Indian people, most video games that portray Natives bolster the hierarchical inequalities that place EuroAmericans on top. In this hierarchy, the creation of digital media has often reinscribed the stereotype that American Indians are victims of Euro-American progress who are stupefied by the advancing technologies of civilization. Because it has been imagined as creating a vast divide between those who have access and those who do not, digital media often further marginalizes already disempowered groups, like Indigenous peoples, by articulating the other as existing in a time not contemporary with those who have access to such media (Ginsburg 2003). In actuality, most Indigenous peoples in the United States have at least some access to digital media, including the internet. This has afforded empowering potentials for many oppressed groups, not only American Indians. Marginalized peoples from all backgrounds have begun to use online access to exchange information, preserve history and cultural knowledge, and enable collective political and social causes (Srinivasan 2006, 497).

Indigenous peoples have also organized collaborations with ethnographers, digital designers, and community elders to craft media that represents and circulates cultural motifs, values, and knowledge (Coleman 2010, 491; Christen 2009, 4-5; Christie 2008, 270; Salazar 2005). By creating their own digital materials, marginalized peoples the world over work to create a counternarrative to the stereotyped portrayals common in dominant media. Indigenous peoples have begun to add video games to their digital repotoire, producing games like Never Alone (Inupiat) and Honor Water (Anishinaabe), that utilize Indigenous artwork to share tribally specific narratives and knowledge (E-Line Media 2016; Walk, Lapensee, and Pinnguaq 2016). They have also created organizations, like Pinnguaq and Skins, with the mission to produce Indigenous centered games (Pinnguaq Association 2013; Fragnito 2010). Indigenous peoples often find it necessary to incorporate their own cultures' epistimologies into their production process as a way to resist adopting the Western perspectives that usually undergird digital media. This furthers their goal of empowerment, and not estrangement, in the materials that they produce. Gabriella Coleman as well as James Curran, and Myung-Jin Park have all argued that digital media created in Native communities is part of the project of "dewesternizing media studies" (Coleman 2010, 491; Park and Curran 1999). In other words, by producing materials which emerge from and embody their own cultural perspective, Indigenous peoples further nonwestern representations in media materials. 
While the idea for the project did not emerge from the Cheyenne community itself, creating a game that portrayed Cheyenne history in an accurate and nuanced manner required collaboration with Cheyenne people. By bringing the game to Cheyenne elders and school children and asking these groups to shape the final product, the creators ensured that representations of Cheyenne people reflected their own cultural perspectives associated with these historical events. Including the four shields connected to four Cheyenne values and emphasizing Little Fox's place is a wider community, structured by kin relationships were powerful ways for the game to present a Cheyenne epistemology. The end result not only reflected Cheyenne cultural perspectives on a period of US history, by privileging Cheyenne voices, it also countered the dominant stereotyped narratives of Plains Indian people as either savages or victims.

Another approach vital to dewesternizing digital media is to respect Indigenous protocol concerning restrictions surrounding the public display of an item or a narrative. These issues get to the heart of Kate Hennessy's question about who has the right to determine how digital cultural heritage should be restricted or circulated (Hennessy 2009, 5-6). Some materials are heavily restricted, particularly religious objects or narratives, and non-Native producers should take extreme caution when creating digital material related to such items. This is of concern in relation to historical narratives as well because a community may have rules surrounding who shares a narrative, who is allowed to hear it, and how it is presented. Even though the Cheyenne experiences surrounding removal and return have been written about extensively by nonCheyenne authors, the narratives describing ancestors' specific experiences are held within the community and even within specific families (Hill 2017). Not all families are comfortable with sharing these narratives. This is another reason why it is important to bring in Cheyenne consultants. The Cheyenne narratives of removal have been privately managed and are very important to Northern Cheyenne understandings of self and community. For them to be circulated publicly, input is necessary. Cheyenne Odyssey focused on narratives shared by the Northern Cheyenne nation to respect the fact that some familial narratives about removal are highly restricted.

When media is not produced by a marginalized community, ensuring their perspectives are represented raises a series of specific challenges. The dominant narrative about Plains Indians is so prevalent that non-Native storytellers may struggle to think beyond it. This is where community collaboration is so vital and often anthropologists can help. An anthropologist with close ties to a community can act as a bridge between Indigenous people and the producers of digital materials or the media itself. Anthropologists are often required to interpret the cultures they interact with to an outside audience, a skill very useful in the production of media. For Cheyenne Odyssey, Mission US writers and producers garnered support from the Dull Knife tribal college president Richard Littlebear, to help to ensure that the game narrated the history of removal and return from a Cheyenne point of view, by providing input on the storyline, the dialogue, and the visual representation of Cheyenne people.

The project even asked for input from Cheyenne school children, who ultimately helped select the name of the game. The creators took the game in its rough stages to Lame Deer schools and encouraged the children to provide feedback while playing it. They also asked for title suggestions, allowing the students to brainstorm several possibilities and then putting the top 
choices to a vote. Mission US used the title the children picked. By seriously considering their input, the writers were not only learning what would appeal most to their target audience, they were privileging the perspective of Cheyenne school children with the goal of creating a game that was culturally meaningful for Cheyenne people. Mission US also asked a Cheyenne flute player, Joseph FireCrow, to create the music for the game (Hill 2016e). This is another way to privilege a Cheyenne audience while undermining the stereotypes held by Euro-American society. Movies often use generic "Indian sounding" music, but Cheyenne Odyssey uses culturally specific music, written and performed by a Cheyenne musician. Littlebear also helped to bring Cheyenne voices to the game, recruiting community members to play the majority of the characters. The preview to the game even includes the Cheyenne language (Hill 2016f). The landscapes pictured in the game recreate real places important to Cheyenne people, so when a Cheyenne player chooses to camp on the Tongue River or Otter Creek, he or she might recognize the bluffs and riverbanks depicted on the screen. These details privilege a Cheyenne audience. They can understand the narrative in their own language and recognize friends and relatives in the voices of the characters. This not only ensures the game reflects Cheyenne perspectives, but makes it personal for the community.

\section{Empowering Northern Cheyenne Community}

By telling the story of a Cheyenne youth who develops a set of positive values based in his culture and uses them to brave incredible danger to remain in his homeland, this game encourages Cheyenne young people today to take pride in their history and identity. The dominant history of westward expansion has the opposite result. Coleman has argued that digital technologies can facilitate social reproduction, "catalyzing 'expansive realizations' of self and culture" (Coleman 2010, 489). When media presents the perspectives of one's own cultural group in a positive light, it can provide such expansive realizations for marginalized peoples. Littlebear noted that, "A Cheyenne Odyssey" is the first game to present the Northern Cheyenne perspective on real events our people experienced" (Thirteen/WNET 2013). The video game is especially relevant for Cheyenne children because it presents aspects of their history in a medium that they enjoying interacting with. Across the United States, including on Indian reservations, digital media has become integrated into everyday life. Anyone with access to the internet has information, music, art, social networks, and games at their fingertips, often right in their pockets if they have a smart phone. Coleman has noted that, "Media has become central to the articulation ...of modes of being in the world" (Coleman 2010,489). When most media depicts American Indian peoples as little more than stereotypes, creating media from an Indigenous view point is essential to the wellbeing of Native communities (Behm-Morawitz and Ta 2014; Burgess et al. 2014; Leonard 2006).

Judy Iseke and Sylvia Moore argue that Indigenous media can create a powerful space for youth to affirm their cultural identity (Iseke and Moore 2011, 21). For Cheyenne players, Cheyenne Odyssey can affirm their connection to their culture and legitimize their specific worldview. They hear their language spoken, witness their culture as a part of daily life, and play out a history that celebrates their ancestors' survival in a video game. The game does this particularly well in the epilogue when it allows the player to follow Little Fox's descendants to the current day (Hill 2016b). The player clicks on each a person from each generation and learns about his 
or her experience in the world, also learning about experiences American Indian people in the United States shared during the twentieth century. Little Fox's son is a part of Buffalo Bill Cody's Wild West Show. Another descendent serves during World War II. Another relative participates in the Red Power movement. The family member of the most current generation is going to medical school. This epilogue reminds both Cheyenne and non-Cheyenne players that many of the Cheyenne living today are descended from the people who survived removal and walked home to the Powder River Valley. It also emphasizes the fact that Cheyenne people are not trapped in an ahistorical past, but live in the same changing world as the rest of us. For Cheyenne children, this is a powerful affirmation of their cultural heritage and their identity as well as a reminder that they are more than the stereotypes imposed on them by non-Native society. Because the entire game tells Cheyenne history from a Cheyenne perspective, Cheyenne players experience the history they hear from their elders validated not only in their schools but by a respected national media organization, PBS. The epilogue is the result of Mission US's multi-faceted collaboration. I suggested to the creators that hegemonic histories of Native peoples tend to end in 1890 , perpetuating the vanishing Indian stereotype. The idea for bringing the game into the present came from collaboration with Northern Cheyenne community members.

Because it is an oral cultural history, the Cheyenne narrative of removal and return translates readily to the visual performativity of the video game. Srinivasan notes that there is a natural linkage between such oral narratives and digital media (Srinivasan 2006, 511). Digital projects also facilitate relationships between youth and elders (Hennessy 2009). Because most elders pass on their knowledge orally, the use of digital media with its emphasis on oral and visual storytelling is a more natural medium than print media for preserving and sharing this knowledge with the community. Furthermore, because young people engage so intently with digital platforms, it can be a potent way to disseminate cultural knowledge. When discussing this topic with a Cheyenne elder, she told me that she believed that digital media might be the most important tool for teaching young people about their culture. She noted that children today spend much of their time in front of the television or computer and rarely have the patience to listen to an elder tell a full story. She also observed that they are much more ready to listen to the narrative if its presented as digital media. While it is still too new to know, hopefully Cheyenne Odyssey will engage young people with their own history and encourage a connection with elders who have more knowledge about the narrative.

It is likely that a Cheyenne player will experience this game differently from a non-Native player. Coleman points out that digital media is provincialized; it does not provide a universality of digital experience (Coleman 2010, 489). Because of the racialization most Native people experience in the United States, as people of color they will consume and interpret video games differently from Euro-Americans, but Native youth immersed in their culture could experience even more extreme dissonance between their lived experience and the representations that they view in games. Usually Euro-American interpretations are privileged because they are often the assumed audience. By including details that privilege a Cheyenne audience, the creators of the game have attempted to ensure that a Cheyenne experiencing the game is equally rewarded compared to a Euro-American player. Furthermore, research shows that Native students often experience conflict between their tribal identity and academic identity, impacting their ability to succeed in most educational institutions (Tynan and Loew 2010). Cheyenne Odyssey and 
educational games like it have the potential to bridge the gaps between these identities, helping Native students to engage fully.

Without guidance from a knowledge teacher, the average non-Native player would gain little more than superficial Cheyenne cultural knowledge from this game. Furthermore, as Reed Stevens, Tom Satwicz, and Laurie McCarthy have demonstrated, players can even undermine the objectives built into a video game through choices made during game play (Stevens, Satwicz, and McCarthy 2008). While the designers intended Little Fox's narrative to reveal the diverse perspectives surrounding westward expansion, players may fail to engage with this message. I would argue, however, that the game as it stands still disrupts the hegemonic narrative because it presents Cheyenne people as actors and not just props in US history. A teacher who chooses to use this video game in his or her curriculum provides students with Little Fox's personal experience of a challenging history. Because the player embodies a Cheyenne youth, it is hard to escape a Cheyenne perspective on encroachment. Even if the teacher emphasizes manifest destiny or the vanishing Indian stereotype, this shift of viewpoint is enough to open the door for conversation.

\section{Conclusion: Indigenous Centered Collaborative Media}

The great potential of the Cheyenne Odyssey video game is that it tells a Cheyenne story from a Cheyenne perspective, empowering Cheyenne youth to take pride in their own history, while it also reaches out to non-Native people, asking them to question the assumptions that they have about westward expansion in the United States by viewing it from the perspective of the original inhabitants of the land that was being settled. Sharing different narratives and allowing for a diversity of perspectives has been a component of American Indian worldviews for centuries. Cheyenne Odyssey embraces this long-standing Indigenous worldview, and represents the potential of digital media to create a new environment for these centuries old practices.

Candice Hopkins has argued that operating along networks that cross great geographical expanses has always been highly valued in American Indian communities because it allows for the influx of new ideas. She argues that this sensibility, as it has been performed since long before the digital age, informs an Indigenous understanding of tradition as fluid and dynamic (Hopkins 2006, 341). Indigenous communities have often been misrepresented as static, but in fact the opposite is true. Hopkins has pointed out that the incorporation of new materials and ideas has actually been a tradition in American Indian communities because it has been recognized as a means of strengthening their societies (Hopkins 2006, 341; Brayboy 2005, 434). For Indigenous people, digital media can cross geographical barriers, bringing Indigenous communities together with each other and with the wider world to share information, strengthening all involved as long as the Indigenous perspective is respected and valued. Ginsburg has noted that media production by Indigenous peoples acts to mediate, not just between the group's own past and future, but also with the dominant culture (Ginsburg 1994). The collaboration built into the production process of Cheyenne Odyssey helped to produce an Indigenous centered game that crosses boundaries to speak to non-Native students as well, providing important but different knowledge to both groups. 
Indigenous forms of storytelling emphasize the relationship between the teller and the listener, recognizing that different versions are appropriate for different audiences. There is not a sense that one version is more accurate than another as long as both are culturally sanctioned. The difference emerges from determining which aspects of the narrative are appropriate to share with each particular audience. As listeners hear a story multiple times over the course of their lives, they learn that each narrative contains many perspectives and yields multiple insights (Basso 1996; Brayboy 2005, 439). Furthermore, as times change, narratives can be reshaped to emphasize the elements that speak to a particular historical moment while retaining the heart of the story. People travel to new landscapes, meet different people, and development new technologies, but traditional stories never seem to loose their relevance. Retelling these stories requires that the narratives be reshaped, but maintaining these narratives-keeping them alive in the community - requires adaptation to new competing demands as well as altered cultural and political contexts (Srinivasan 2006, 498; Ong 2013; Goody and Watt 1968).

While digital media approximate many elements of oral narrative, its flexibility is very difficult to retain. As Iseke and Moore recognize, the digitization of narratives freezes them in film or text, denying the teller the ability to reshape the narrative for different listeners, in turn reducing the complexity of the narrative (Iseke and Moore 2011, 29). One possible solution is producing multiple versions of a narrative for multiple audiences, for example, presenting the same story in different forms for small children than for adults. Digital media allows for this type of multiplicity more readily than text or even videos. Furthermore, working in consultation with elders helps to address these types of concerns. Digital storytellers need to discuss with elders which parts of the story are vital to conveying its message and which are details added to draw in specific audiences, allowing elders control over deciding which changes to a narrative are appropriate and which are not.

A first-person video game, like Cheyenne Odyssey, does have benefits for retaining the nuances of Indigenous narrative. A first-person game can reflect multiple perspectives at once because the narrative changes depending on which options a given player chooses. Such a game provides multiple possibilities at each junction in the story and therefore, multiple narratives depending on the player's proclivities. Consider the example at the beginning of Cheyenne Odyssey, when the player discovers that the horses Little Fox was supposed to be watching have gone missing. The player can make bolder choices, teasing the older boy with Little Fox and searching for the horses him or herself, traveling further and further from camp (Hill 2016g). Or s/he can make more restrained choices, reporting the loss to Little Fox's uncle and getting advice from an older person before acting. The game presents very real consequences for this relatively minor decision. The player learns that the horses were driven away by Crow warriors and pursuing them alone would be very dangerous for Little Fox. In this way, one narrative - the coming of age of one character-can reflect Cheyenne perspectives on bravery and expectations surrounding facing an enemy but can also reflect ideas about wisdom and relationships between adults and youths within a family. Although digital media portrays Indigenous narratives in ways quite different from traditional storytelling, with careful consideration and community collaboration, Indigenous materials can be presented digitally in ways that continue to fulfill some of the traditional purposes of storytelling. 
Often American Indian experience is devalued in dominant historical narratives (Brayboy 2005, 426-27). It can be left out entirely or presented in an overly simplistic fashion. The exposure to stereotyped representations of American Indian people, not only in popular media, but also in academic curriculum, leaves non-Native young people with highly problematic understandings of the Native people who share their landscape. It also creates a narrative that is unrecognizable to Native people, leaving Native students with the unsettling experience of learning a narrative in school that contradicts the history they have learned from their relatives. Through collaboration with Cheyenne community members, Cheyenne Odyssey is able to present a Cheyenne perspective on US expansion, breaking down stereotypes and encouraging students to identify with a Native view of these historical events. This game provides an innovative educational tool for the wider public as well as a means to preserve Cheyenne history for the community. By bringing a Cheyenne perspective to the dominant narrative of westward expansion, Cheyenne Odyssey narrates history with meaning to both Native and non-Native students as well.

\section{Note}

1. For example, consider the games: Red Dead Redemption and its newer release, Red Dead Redemption II, Call of Juarez: Bound in Blood, Wild West Online, and Boot Hill Heroes.

\section{References Cited}

Basso, Keith H. 1996. Wisdom Sits in Places: Landscape and Language among the Western Apache. Albuquerque: University of New Mexico Press.

Behm-Morawitz, Elizabeth and David Ta. 2014. "Cultivating Virtual Stereotypes?: The Impact of Video Game Play on Racial/Ethnic Stereotypes." Howard Journal of Communications 25 (1): 1-15. https://doi.org/10.1080/10646175.2013.835600

Brayboy, Bryan. 2005. "Toward a Tribal Critical Race Theory in Education.” The Urban Review 37 (5): 425-46. https://doi.org/10.1007/s11256-005-0018-y

Burgess, Melinda C. R., Karen E. Dill, S. Paul Stermer, Stephen R. Burgess, and Brain P. Brown. 2011. "Playing With Prejudice: The Prevalence and Consequences of Racial Stereotypes in Video Games." Media Psychology 14 (3): 289-311. https://doi.org/10.1080/15213269.2011.596467

Christen, Kimberly. 2009. "Access and Accountability: The Ecology of Information Sharing in the Digital Age.” Anthropology News 50 (4): 4-5. https://doi.org/10.1111/j.1556$\underline{3502.2009 .50404 . x}$

Christie, Michael. 2008. "Digital Tools and the Management of Australian Aboriginal Desert Knowledge." In Global Indigenous Media: Cultures, Poetics, and Politics, edited by Pamela Wilson and Michelle Stewart, 270-86. Durham, NC: Duke University Press. 
Cohen, Hart and Juan F. Salazar. 2005. "Introduction: Prospects for a Digital Anthropology." Media International Australia 116 (1): 5-9. https://doi.org/10.1177/1329878X0511600103

Coleman, Gabriella. 2010. "Ethnographic Approaches to Digital Media.” Annual Review of Anthropology 39: 487-505. https://doi.org/10.1146/annurev.anthro.012809.104945

Duarte, Marisa Elena, and Miranda Belarde-Lewis. 2015. "Imagining: Creating Spaces for Indigenous Ontologies.” Cataloging and Classification Quarterly 53 (5-6): 677-702. https://doi.org/10.1080/01639374.2015.1018396

Eglash, Ron, and Audrey Bennett. 2009. “Teaching with Hidden Capital: Agency in Children's Computational Explorations of Cornrow Hairstyles." Children Youth and Environments 19 (1): 58-73. http://www.jstor.org/stable/10.7721/chilyoutenvi.19.1.0058

E-Line Media. 2016. Never Alone Accessed May 6, 2018. http://neveralonegame.com.

Fragnito, Skawennati. 2010. “AbTec.” Accessed May 6, 2018. http://www.skins.abtec.org.

Ginsburg, Faye. 1991. “Indigenous Media: Faustian Contract or Global Village?” Cultural Anthropology 6 (1): 92-112. https://doi.org/10.1525/can.1991.6.1.02a00040

- - . 1994. "Culture/Media: A (Mild) Polemic.” Anthropology Today 10 (2): 5-15. https://doi:10.2307/2783305

- - - 2003. "Embedded Aesthetics: Creating a Discursive Space for Indigenous Media." In Critical Cultural Policy Studies: A Reader, edited by Justin Lewis and Toby Miller, 8899, Malden, MA: Blackwell.

Hennessy, Kate. 2009. "Virtual Repatriation and Digital Cultural Heritage: The Ethics of Managing Online Collections.” Anthropology News 50 (4): 5-6. https://doi.org/10.1111/j.1556-3502.2009.50405.x

Hill, Christina Gish. 2016a. "Badges Mission US Cheyenne Odyssey 1.” [Gameplay Video.] Accessed May 6, 2018. https://youtu.be/rUeZQeSHiwc

- - . 2016b. "Epilogue Mission US Cheyenne Odyssey 1." [Gameplay Video.] Accessed May 9, 2018. https://youtu.be/k9dKhILeSis

- - . 2016c. "Finding the Horses Mission US Cheyenne Odyssey 1." [Gameplay Video.] Accessed May 6, 2018. https://youtu.be/mqnhFhwCoU0

- - . 2016d. "Heading North Mission US Cheyenne Odyssey 1." [Gameplay Video.] Accessed May 6, 2018. https://youtu.be/R69Q5ZZIibA 
- - . 2016e. "Joseph FireCrow's Flute Mission US Cheyenne Odyssey 1.” [Gameplay Video.] Accessed May 6, 2018. https://youtu.be/ON5tDFkET8Y

- - . 2016f. "Preview Mission US Cheyenne Odyssey 1." [Gameplay Video.] Accessed May 6, 2018. https://youtu.be/3DO2-dHVaxw

- - . 2016g. "Stolen Horses Bravery Mission US Cheyenne Odyssey 1." [Gameplay Video.] Accessed May 9, 2018. https://youtu.be/rQnOM3T9jqo

- - . 2016h. "Trading Mission US Cheyenne Odyssey 1." [Gameplay Video.] Accessed May 6, 2018. https://youtu.be/azGf40Tq3ng

- - . 2016i. "Train Mission US Cheyenne Odyssey 1." [Gameplay Video.] Accessed May 6, 2018. https://youtu.be/YvHfDnkusq8

- - - 2017. Webs of Kinship: Family in Northern Cheyenne Nationhood. Norman: University of Oklahoma Press.

Hopkins, Candice. 2006. "Making Things Our Own: The Indigenous Aesthetic in Digital Storytelling." Leonardo 39 (4): 341-44. https://doi.org/10.1162/leon.2006.39.4.341

Isaac, Gwyneira. 2015. "Perclusive Alliances: Digital 3-D, Museums, and the Reconciling of Culturally Diverse Knowledges.” Current Anthropology 56 (S12): S286-96. https://doi.org/10.1086/683296

Iseke, Judy, and Sylvia Moore. 2011."Community-based Indigenous Digital Storytelling with Elders and Youth." American Indian Culture and Research Journal 35 (4): 19-38. https://doi.org/10.17953/aicr.35.4.4588445552858866

Leonard, David J. 2006. “Not a Hater, Just Keepin' It Real: The Importance of Race- and Gender-Based Game Studies." Games and Culture 1 (1): 83-88. https://doi.org/10.1177/1555412005281910

Matte, Christy. 2013. "A Game Review of "Mission US: A Cheyenne Odyssey." Common Sense Media, accessed June 7, 2016, https://www.commonsensemedia.org/gamereviews/mission-us-a-cheyenne-odyssey\#

Mission US n.d. a. "Cheyenne Odyssey.” Accessed May 6, 2018, http://www.missionus.org/pages/landing-mission-3

Mission US n.d. b. "What is Mission US? Accessed May 6, 2018, http://www.missionus.org/pages/about

Ong, Walter J. 2013. Orality and Literacy: The Technologizing of the Word. 3rd Edition, New York: Routledge. 
Park, Myung-Jin, and James Curran. 1999. De-Westernizing Media Studies. New York: Routledge.

Pinnguaq Association. 2013. "Pinnguaq.” Accessed May 6, 2018. http://www.pinnguaq.com

Powers, Meredith. 2014. "Mission US: A Cheyenne Odyssey," New Learning Times, accessed June 7, 2016 https://newlearningtimes.com/cms/article/2113

PR Newswire Services. 2013. "Mission US “A Cheyenne Odyssey” Gives Middle Grade Students a Plains Indian Perspective on Westward Expansion in the United States," Oct. 16. Accessed June 7, 2016. http://www.prnewswire.com/news-releases.

Salazar, Juan Francisco. 2005. "Digitising Knowledge: Anthropology and New Practices of Digitextuality." Media International Australia 116 (1): 64-74. https://doi.org/10.1177/1329878X0511600108

Sol Worth and John Adair. 1997. Through Navajo Eyes: An Exploration in Film Communication and Anthropology. New Edition, Albuquerque: University of New Mexico Press.

Srinivasan, Ramesh. 2006. "Indigenous, Ethnic and Cultural Articulations of New Media." International Journal of Cultural Studies 9 (4): 497-518. https://doi.org/10.1177/1367877906069899

Stevens, Reed, Tom Satwicz, and Laurie McCarthy. 2008. "In-Game, In-Room, In-World: Reconnecting Video Game Play to the Rest of Kids' Lives." In The Ecology of Games: Connecting Youth, Games, and Learning, edited by Katie Salen Tekinbaş, 41-66. Cambridge, MA: MIT Press.

Thirteen/WNET. 2013. “Mission US ‘A Cheyenne Odyssey’ Gives Middle Grade Students a Plains Indian Perspective on Westward Expansion in The United States." Accessed May 6, 2018. https://www .thirteen .org/13pressroom/press-release/mission-us-a-cheyenneodyssey/

Turner, Terence. 1992. "Defiant Images: The Kayapo Appropriation of Video.” Anthropology Today 8 (6): 5-16. http://www.jstor.org/stable/2783265

Tynan, Timothy, and Patty Loew. 2010. “Organic Video Approach: Using New Media to Engage Native Youth in Science." American Indian Culture and Research Journal 34 (4): 31-40. https://doi.org/10.17953/aicr.34.4.078377662754gg57

Walk, Nibi, Elizabeth Lapensee, and Pinnguaq. 2016. Honour Water. Accessed May 6, 2018. http://www.honourwater.com/about/\#bio

Goody, Jack and Ian Watt, Ian. 1968. "The Consequences of Literacy.” In Literacy in Traditional Societies, edited by Jack Goody, 27-68. New York: Cambridge University Press. 
Christina Gish Hill is an Associate Professor in the World Languages and Cultures department at Iowa State University. She focuses on American Indian/Native cultures of the Northern Plains, using the methodologies of ethnography and ethnohistory to research the employment of cultural and political expressions of social cohesion by Native communities. She has recently published a book, entitled Webs of Kinship: Family in Northern Cheyenne Nationhood (Norman: University of Oklahoma Press, 2017), on the use of kinship by Northern Cheyenne peoples to exercise political autonomy. She has also contributed to American Indian Culture and Research Journal, American Indian Quarterly, The Routledge History of American Foodways (New York: Routledge, 2018), and Tribal Worlds: Critical Studies in American Indian Nation Building (Albany, NY: SUNY Press, 2014).

https://doi.org/10.14434/mar.v12i2.22420 